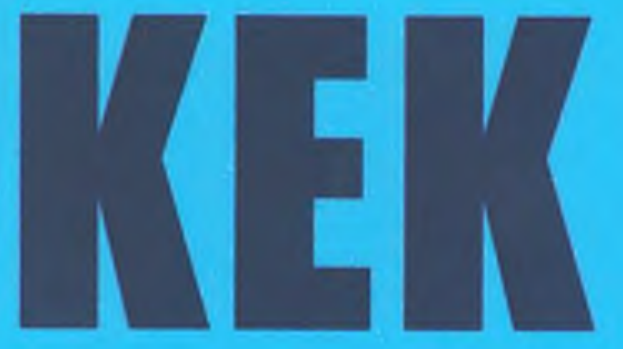

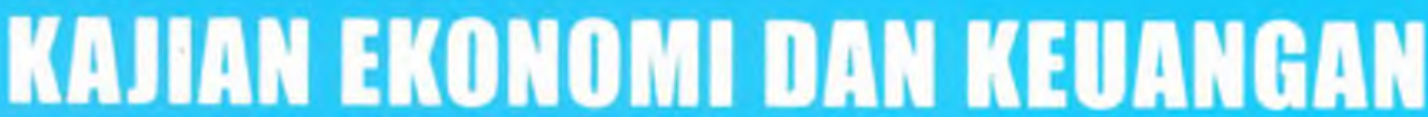

- Analisis Urgensitas Pinjaman Luar Negeri Indonesia Dalam Rangka Pembiayaan Defisit APBN

- Phasing Out Kerosene Subsidy in Developing Countries. Case Study of India and Indonesia

- Kontribusi, Efektivitas, Efisiensi, dan Faktorfaktor yang Mempengaruhi Penerimaan Pajak Pertambahan Nilai

- Studi Potensi Pendanaan Climange Change Pada Lembaga Keuangan Multilateral

- Tax Harmonization ASEAN Melalui ASEAN Tax Forum : Pembelajaran Dari Proses Tax Harmonization Eropa

\begin{tabular}{|c|c|c|c|c|c|}
\hline Kaj. Eko. Keu. & Vol. 16 & No.1 & Jaharta 2011 & $\begin{array}{c}\text { ISSN 1410- } \\
3249\end{array}$ & $\begin{array}{c}\text { Terakreditasi } 8 \\
\text { (No. Akreditasi: } \\
\text { 30B/AU2/P2MBU08/2010) }\end{array}$ \\
\hline
\end{tabular}

Pusat Kebijakan Ekonomi Makro

Badan Kebijakan Fiskal

Kementerian Keuangan

Republlk Indonesia 


\section{K A J I A N}

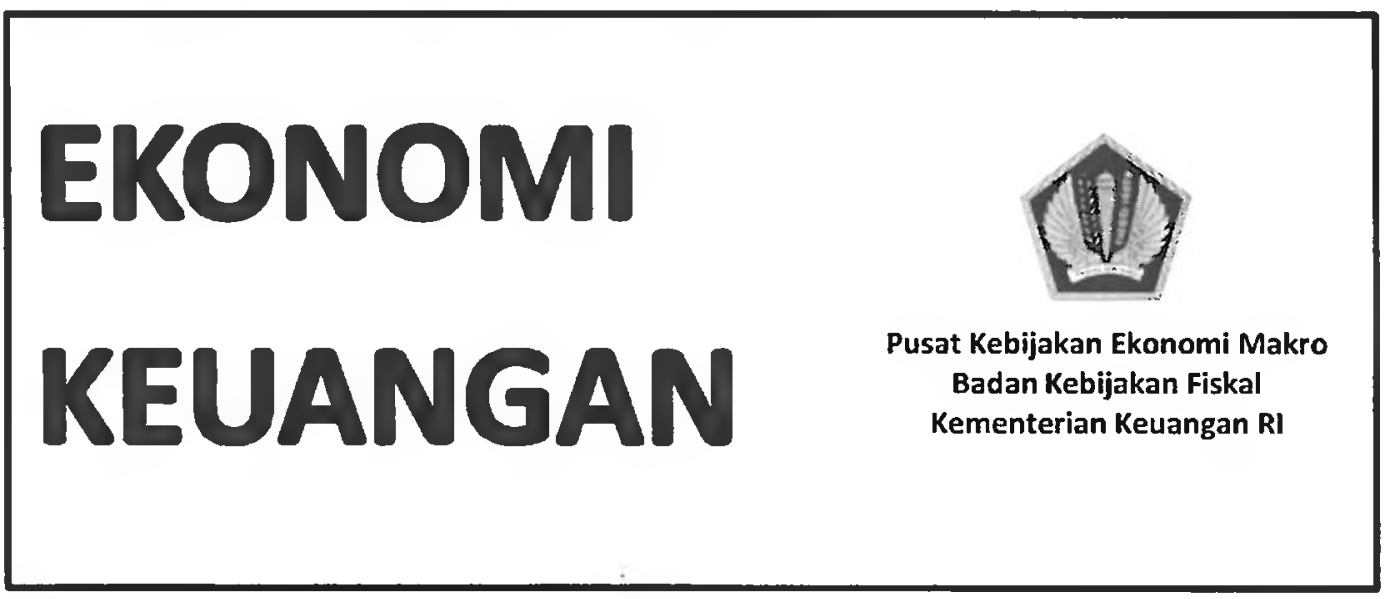

Analisis Urgensitas Pinjaman Luar Negeri Indonesia Dalam

Rangka Pembiayaan Defisit APBN

Phasing Out Kerosene Subsidy in Developing Countries. Case

Study of India and Indonesia

Kontribusi, Efektivitas, Efisiensi dan Faktor-faktor yang

Mempengaruhi Pajak Pertambahan Nilai

Studi Potensi Pendanaan Climate Change Pada Lembaga Keuangan Multilateral

Tax Harmonization ASEAN Melalui ASEAN Tax Forum : Pembelajaran

Dari Proses Tax Harmonization Eropa

\begin{tabular}{|l|l|l|l|l|}
\hline Kaj. Eko. \& Keu. & Vol. 15 & No.1 & Jakarta 2011 & ISSN 1410-3249 \\
\hline
\end{tabular}




\section{KATA SAMBUTAN}

Kami panjatkan rasa syukur kepada Tuhan Yang Maha Esa atas terbitnya Kajian Ekonomi dan Keuangan edisi ini ke hadapan pembaca sekalian. Pada edisi ini, kami menyajikan berbagai topik yang berkaitan dengan analisis dan dampak kebijakan publik di bidang ekonomi dan keuangan negara.

Kajian pada volume kali ini diisi oleh berbagai topik tulisan yaitu Analisis Urgensitas Pinjaman Luar Negeri Indonesia Dalam Rangka Pembiayaan Defisit APBN; Phasing Out Kerosene Subsidy in Developing Countries. Case Study of India and Indonesia; Kontribusi, Efektivitas, Efisiensi, dan Faktor-faktor yang Mempengaruhi Penerimaan Pajak Pertambahan. Nilai; Studi Potensi Pendanaan Climange Change Pada Lembaga Keuangan Multilateral; dan Tax Harmonization ASEAN Melalui ASEAN Tax Forum : Pembelajaran Dari Proses Tax Harmonization Eropa. Adapun para penulis yang berkontribusi pada penerbitan kali ini yaitu Abdul Aziz, Mahpud Sujai, M. Syarif Mulyadi, R. Nurhidajat, Sigit Setiawan, Suska dan Yuventus Effendi.

Demikianlah kata pengantar yang dapat kami sampaikan. Ibarat peribahasa tiada gading yang tak retak, maka kami menyadari kajian ini tentunya masih terdapat kekurangan baik yang disengaja maupun yang tidak kami sengaja. Oleh karena itu, kami mengharapkan masukan dari para pembaca guna perbaikan di masa yang akan datang. Selanjutnya, kami berharap jurnal ini dapat memberikan manfaat kepada para pembaca sekalian. Selamat membaca!

Jakarta, 2011

Dewan Redaksi 


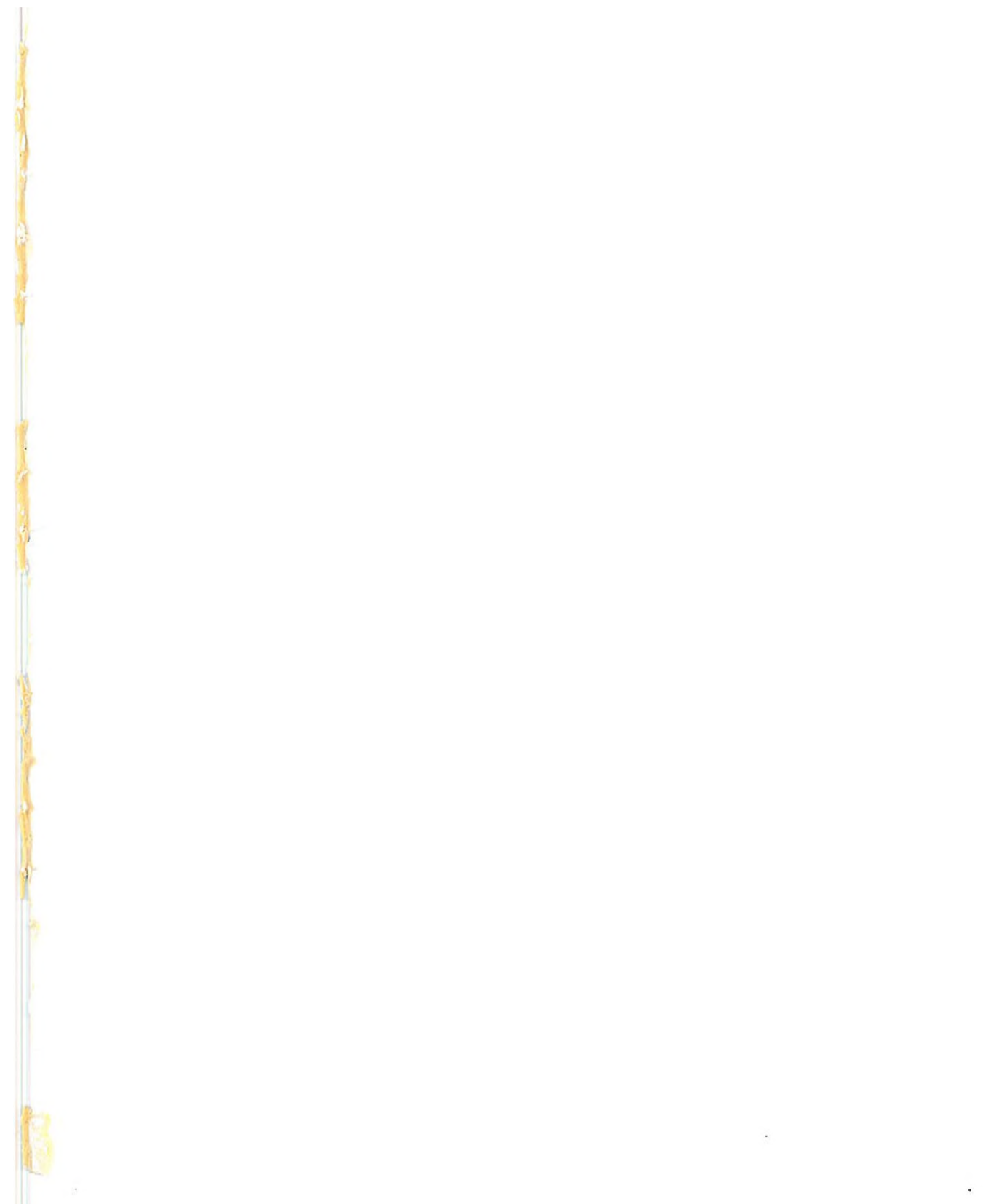




\section{DAFTAR ISI}

\section{Cover}

Dewan Redaksi ................................................................................................................. ii

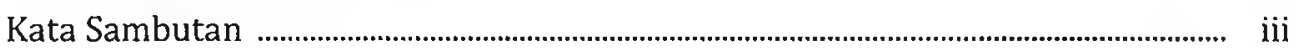

Daftar Isi ............................................................................................................................. $\quad \mathrm{v}$

Daftar Tabel ................................................................................................................. vi

Daftar Gambar .................................................................................................................. vii

Kumpulan Abstraksi ................................................................................................................ ix

ANALISIS URGENSITAS PINJAMAN LUAR NEGERI INDONESIA DALAM RANGKA PEMBIAYAAN DEFISIT APBN

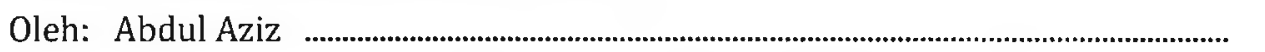

PHASING OUT KEROSENE SUBSIDY IN DEVELOPING COUNTRIES.

CASE STUDY OF INDIA AND INDONESIA

Oleh: Mahpud Sujai

KONTRIBUSI, EFEKTIVITAS, EFISIENSI, DAN FAKTOR-FAKTOR YANG MEMPENGARUHI PENERIMAAN PAJAK PERTAMBAHAN NILAI

Oleh: M. Syarif Mulyadi

Studi Potensi Pendanaan Climange Change Pada Lembaga

Keuangan Multilateral

Oleh: R. Nurhidajat dan Sigit Setiawan

Tax Harmonization ASEAN Melalui ASEAN Tax Forum :

Pembelajaran Dari Proses Tax Harmonization Eropa

Oleh: Suska dan Yuventus Effendi 87 


\section{DAFTAR TABEL}

\section{ANALISIS URGENSITAS PINJAMAN LUAR NEGERI INDONESIA DALAM RANGKA PEMBIAYAAN DEFISIT APBN}

Tabel 2.1. Ringkasan APBN 2001-2009

Tabel 2.2. Perkembangan Penerimaan Negara Pada APBN 2001 s.d. APBN 2009

Tabel 2.3. Perkembangan Belanja Negara Pada APBN 2001 s.d. APBN 2009 .. 7

Tabel 3.1. Penarikan Pinjaman Luar Negeri dan Defisit Anggaran ....................... 12

Tabel 3.2. Penarikan dan Pembiayaan PLN Negara Indonesia Tahun Anggaran 2002 s.d. 2009

Tabel 3.3. Rasio Pembayaran PLN Terhadap Penarikan PLN ................................... 14

Tabel 3.4. Model Dugaan Pinjaman Luar Negeri Indonesia ...................................... 15

Tabel 3.5. White Heteroske da Sticity Test ....................................................................... 16

Tabel 3.6. Correlation Matrix ...................................................................................... 16

Tabel 3.7. Breusch-Godfrey Serial Correlation LM Test .......................................... 17

Tabel 3.8. Pembiayaan Non Utang 2010 dan 2011 .................................................. 25

Tabel 3.9. Perkembangan Pinjaman Pemerintah Negara Indonesia Tahun 1998 dan 2009

PHASING OUT KEROSENE SUBSIDY IN DEVELOPING COUNTRIES.

\section{CASE STUDY OF INDIA AND INDONESIA}

Table 3.1. Fuel Subsidy in India

\section{STUDI POTENSI PENDANAAN CLIMANGE CHANGE PADA LEMBAGA}

\section{KEUANGAN MULTILATERAL}

Tabel 5.1. Distribusi Proyek CDM di Asia Tenggara

\section{TAX HARMONIZATION ASEAN MELALUI ASEAN TAX FORUM :}

\section{PEMBELAJARAN DARI PROSES TAX HARMONIZATION EROPA}

Tabel 2.1. Perkembangan Harmonisasi Pajak Uni Eropa .......................................... 94

Tabel 3.1. Tarif Pajak Tidak Langsung Negara ASEAN ................................................ 95

Tabel 3.2. Tarif Pajak Penghasilan Badan Negara ASEAN ........................................ 96

Tabel 3.3. Daftar Tax Treaty Indonesia dengan Negara ASEAN ............................. 96

Tabel 3.4. Daftar Tax Treaty Antar Negara ASEAN ...................................................... 97

Tabel 3.5. Intra- and Extra-ASEAN Trade, 2009 ........................................................ 98

Tabel 3.6. Rasio Penerimaan Pajak terhada PDB dari Negara Anggota ASEAN Periode 1996-2009 .......................................................................... 99

Tabel 3.7. Tarif Pajak Tidak Langsung Negara Uni Eropa 2004-2009 .................. 100

Tabel 3.8. Tarif Pajak Langsung Negara Uni Eropa1999-2009 ............................... 101 


\section{DAFTAR GAMBAR}

\section{ANALISIS URGENSITAS PINJAMAN LUAR NEGERI INDONESIA DALAM RANGKA PEMBIAYAAN DEFISIT APBN}

Grafik 3.1. Komposisi SUN Tidak Ideal ................................................................. 27

Grafik 3.2. Komposisi SUN Ideal ......................................................................... 27

\section{PHASING OUT KEROSENE SUBSIDY IN DEVELOPING COUNTRIES. CASE STUDY OF INDIA AND INDONESIA}

Picture 3.1. Fuel Subsidy Formula ………………................................................................. 39

Picture 3.2. Kerosene to LPG Conversion Road Map .................................................. 41

Picture 3.3. Consumption Volume of Kerosene and LPG ......................................... 43

Picture 3.4. The Amount of Subsidized Kerosene and LPG ..................................... 43

Picture 3.5. Proportion of Kerosene to LPG Usage ................................................... 44

Picture 3.6. Estimated Amount of Subsidy Diversion in India ................................ 46

KONTRIBUSI, EFEKTIVITAS, EFISIENSI, DAN FAKTOR-FAKTOR YANG MEMPENGARUHI PENERIMAAN PAJAK PERTAMBAHAN NILAI

Grafik 3.1. Tax Ratio (dalam persen) ......................................................................... 60

Grafik 3.2. Perkembangan PDB, Konsumsi Nasional dan Penerimaan PPN (dalam miliar Rp) 61

Grafik 3.3. Peran PPN dan PPh Terhadap Total Penerimaan Perpajakan (dalam persen) 62

Grafik 3.4. Kontribusi Penerimaan PPN dan PPh Dalam Membiayai Belanja Pemerintah(dalam persen) ............................................................. 64

Grafik 3.5. Perkembangan Penerimaan Pajak (dalam miliar rupiah) ................... 65

Grafik 3.6. Kinerja Penerimaan PPN ................................................................................ 66

Grafik 3.7. Potensi dan Realisasi PPN (dalam triliun RP) ......................................... 67

Grafik 3.8. Gap Antara Potensi dan Realisasi PPN (dalam triliun RP) ................. 67

STUDI POTENSI PENDANAAN CLIMANGE CHANGE PADA LEMBAGA KEUANGAN MULTILATERAL

Gambar 3.1 Diagram Mekanisme Kerja CDM

Gambar 6.1 Mobilisasi Pembiayaan Dengan Mekanisme Pasar ................................... 81

TAX HARMONIZATION ASEAN MELALUI ASEAN TAX FORUM : PEMBELAJARAN DARI PROSES TAX HARMONIZATION EROPA 


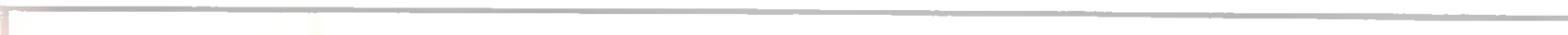




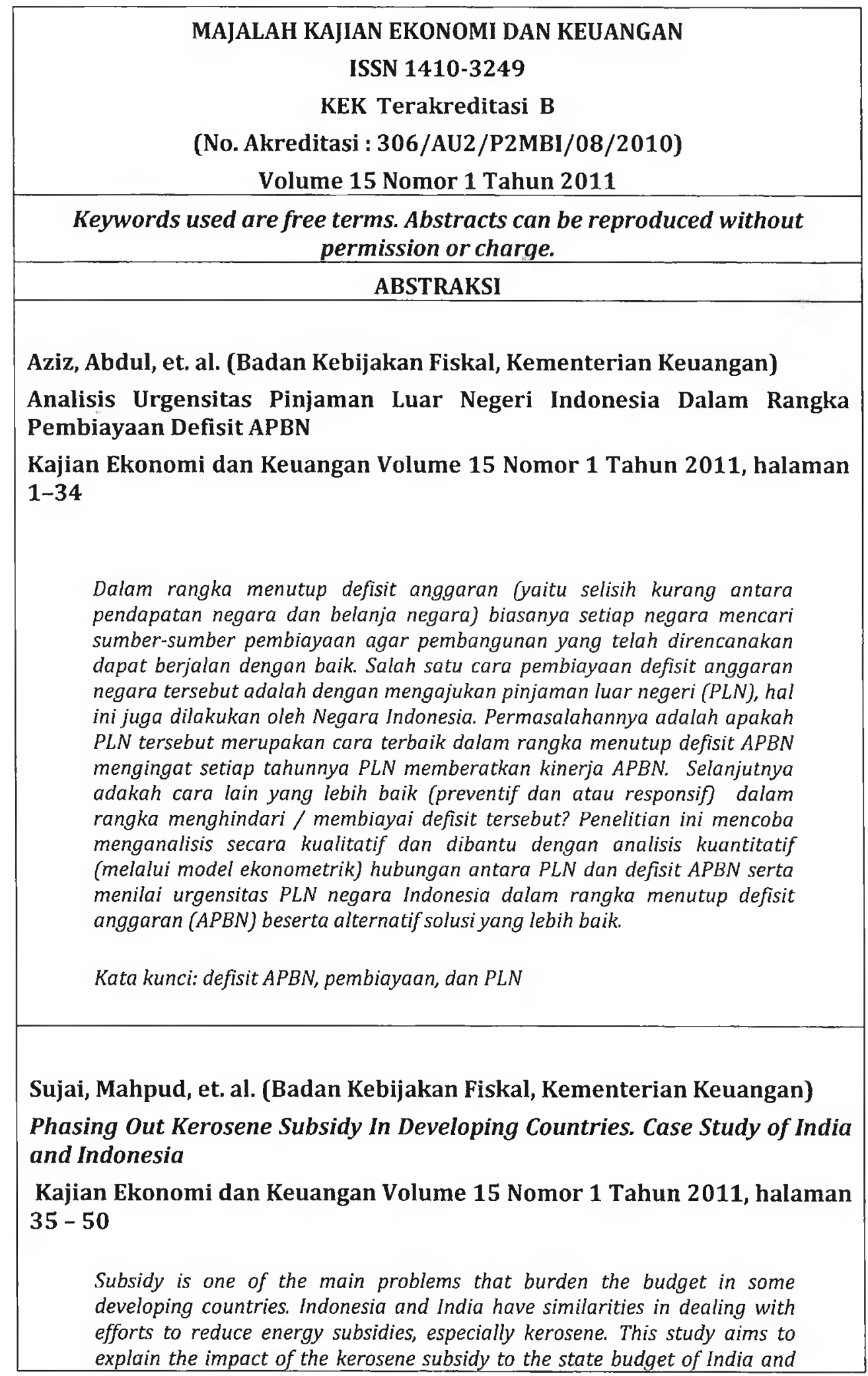




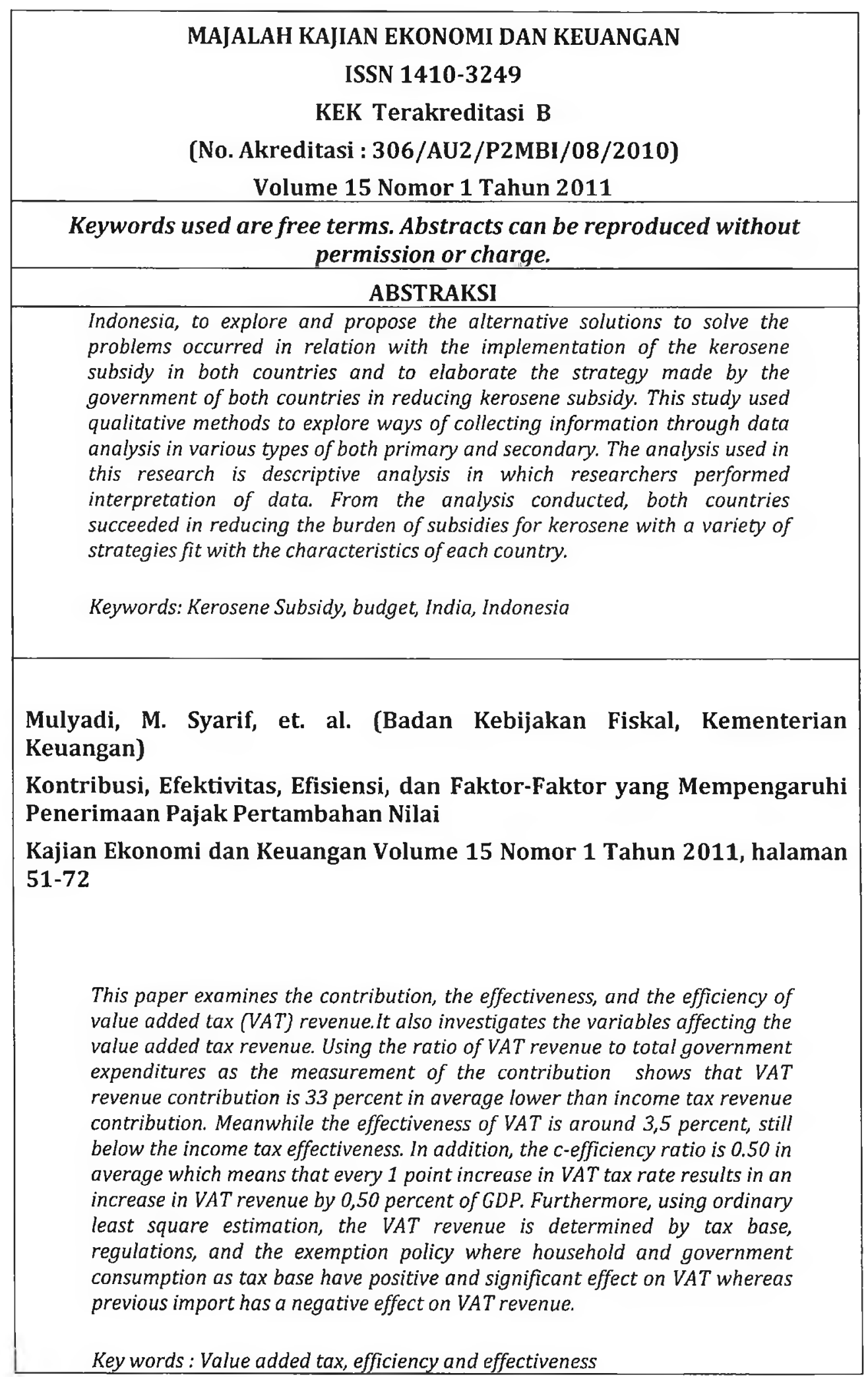




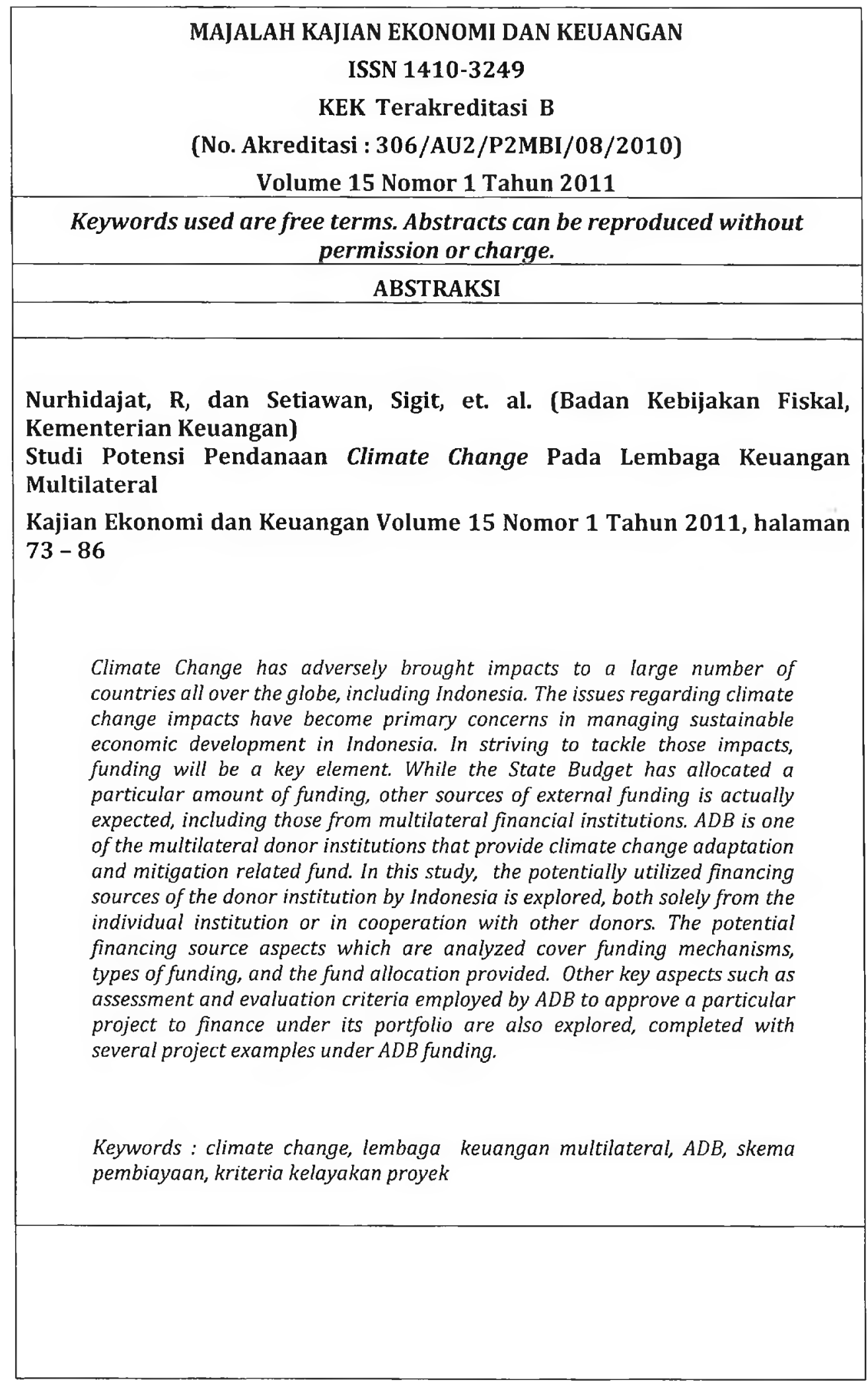




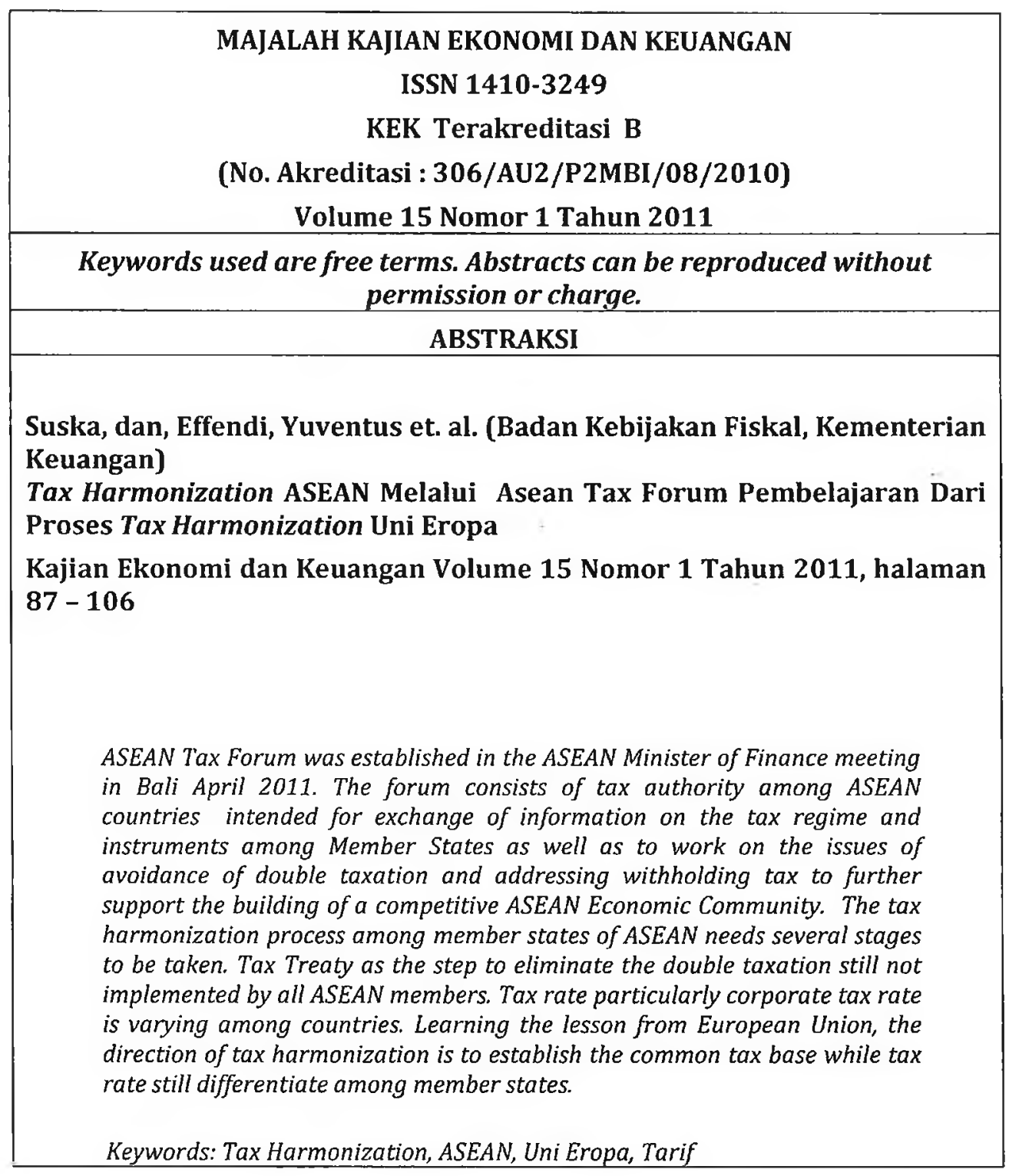




\title{
STUDI POTENSI PENDANAAN CLIMATE CHANGE PADA LEMBAGA KEUANGAN MULTILATERAL
}

oleh :

R. Nurhidayat ${ }^{1}$

Sigit Setiawan

\begin{abstract}
Climate Change has adversely brought impacts to a large number of countries all over the globe, including Indonesia. The issues regarding climate change impacts have become primary concerns in managing sustainable economic development in Indonesia. In striving to tackle those impacts, funding will be a key element. While the State Budget has allocated a particular amount of funding, other sources of external funding is actually expected, including those from multilateral financial institutions. $A D B$ is one of the multilateral donor institutions that provide climate change adaptation and mitigation related fund. In this study, the potentially utilized financing sources of the donor institution by Indonesia is explored, both solely from the individual institution or in cooperation with other donors. The potential financing source aspects which are analyzed cover funding mechanisms, types of funding, and the fund allocation provided. Other key aspects such as assessment and evaluation criteria employed by ADB to approve a particular project to finance under its portfolio are also explored, completed with several project examples under $A D B$ funding.

Keywords : climate change, lembaga keuangan multilateral, $A D B$, skema pembiayaan, kriteria kelayakan proyek
\end{abstract}

\section{LATAR BELAKANG}

Dari sisi struktur pengelolaannya, dana untuk pembiayaan perubahan iklim terbagi atas dua kelompok, yaitu dana-dana yang dikoordinasikan oleh United Nations Framework Convention on Climate Change (UNFCCC) atau dikenal dengan istilah informalnya convention funds dan dana yang diadministrasikan oleh lembaga-lembaga bilateral, Bank Dunia, atau Jembaga-lembaga multilateral lainnya yang dikenal dengan istilah non-convention funding initiatives. Kedua jenis sumber dana tersebut saat ini telah secara nyata diimplementasikan. Dalam sidang UNFCCC terakhir di Cancun, Mexico (COP 16) pada bulan Desember 2010, telah

\footnotetext{
${ }^{1}$ Kedua penulis adalah peneliti pada Badan Kebijakan Fiskal, Kementerian Keuangan
} 
Kajian Ekonomi dan Keuangan, Volume 15 No. 1 Tahun 2011

disepakati komitmen penyediaan dana oleh negara-negara maju yang tergabung dalam Annex 1 sebesar US $\$ 100$ milyar per tahun sejak tahun 2011 hingga $2020^{2}$. Sedangkan dari sisi non-convention funding initiatives yang dipelopori oleh lembaga-lembaga donor multilateral, telah disalurkan berbagai pembiayaan proyek yang terkait dengan adaptasi dan mitigasi perubahan iklim ke berbagai negara berkembang. Bahkan Asian Development Bank (ADB) telah menempatkan pembangunan dalam kerangka perubahan iklim sebagai salah satu prioritas dalam penyaluran dananya.

Penyaluran dana terkait dengan perubahan iklim dapat melalui berbagai mekanisme. Dari skema di bawah UNFCCC kita telah mengenal beberapa mekanisme, di antaranya adalah melalui Mekanisme Pembangunan bersih atau Clean Development Mechanism (CDM) dan Reducing emissions from deforestation and forest degradation in developing countries (REDD). Melalui mekanisme CDM, negara-negara berkembang dapat menciptakan proyek yang berdampak pada pengurangan emisi hingga mendapatkan kredit pengurangan emisi yang telah diverifikasi kebenarannya atau Certified Emissions Reduction (CERs). CERs tersebut kemudian dapat dijual ke pasar di mana negara-negara industri dapat membelinya untuk memenuhi bagian dari target pengurangan emisi mereka sesuai Protokol Kyoto. Sedangkan REDD merupakan mekanisme yang dapat memberi insentif bagi negara-negara berkembang setelah negara tersebut berhasil mengurangi emisi sebagai hasil dari pengurangan deforestrasi dan degradasi hutan melalui mekanisme internasional. Dengan mekanisme-mekanisme tersebut, diharapkan negara-negara berkembang tetap dapat meneruskan pembangunannya dengan tetap berwawasan lingkungan melalui pemanfaatan dana-dana internasional.

Akan tetapi dalam pelaksanaannya negara berkembang, khususnya negaranegara di kawasan Asia Tenggara, memiliki banyak kendala dalam memanfaatkan berbagai mekanisme pembiayaan yang terkait dengan climate change tersebut (UNEP, 2009). Kendala tersebut terutama meliputi kendala teknologi, finansial, institusional, dan pasar. Dari sisi finansial misalnya, negara berkembang terkendala masalah biaya transaksi. Kebanyakan proyek di negara berkembang adalah berskala kecil dan hal ini membuat biaya transaksi proyek tersebut tidak efesien.

Menghadapi kendala-kendala tersebut, Indonesia sebagai bagian dari negara berkembang, perlu mencari solusi alternatif dalam pengembangan pembangunan yang berkelanjutan dalam kerangka climate change. Sumber pembiayaan dari nonconvention funding initiatives merupakan alternatif yang perlu dikaji lebih dalam. Sumber pembiayaan jenis ini memiliki sumber yang berbeda-beda. Dengan lembaga yang berbeda-beda, persyaratan atau mekanisme pembiayaannya pun memiliki ragam yang berbeda. Diperlukan penelaahan yang mendalam terkait mekanisme

\footnotetext{
${ }^{2}$ Sumber: situs UNFCCC
} 
yang ada pada masing-masing lembaga tersebut. Salah satu lembaga donor multilateral yang menyalurkan dana terkait adaptasi dan mitigasi perubahan iklim adalah Asian Development Bank (ADB).

Asian Development Bank merupakan lembaga pembiayaan multilateral yang secara historis didedikasikan untuk membantu kelanjutan pembangunan di kawasan Asia Pasifik. ADB merupakan bagian dari lembaga yang menyediakan nonconvention funding initiatives. Dengan latar belakang tersebut, penelitian ini mencoba menggali potensi pembiayaan dalam kerangka perubahan iklim yang berasal dari lembaga donor tersebut.

\section{TUJUAN PENELITIAN}

Melalui penelitian ini, diharapkan akan tergambar dengan jelas programprogram pembiayaan $\mathrm{ADB}$, peluang serta persyaratan apa yang harus Indonesia segera penuhi agar program-program yang tersedia dapat dimanfaatkan oleh Indonesia dengan optimal. Oleh karena itu, dengan menggunakan pendekatan deskriptif-eksploratif penelitian ini bertujuan untuk (1) mengetahui apakan terdapat mekanisme lain yang dimiliki oleh non-convention funding initiatives dalam hal ini ADB yang dapat menjawab berbagai kelemahan yang ada pada convention fund. (2) mengetahui jenis dan seberapa besar pagu dana yang disediakan oleh ADB yang terkait dengan perubahan iklim (3) mengetahui kriteria yang digunakan ADB dalam menyeleksi proposal proyek. (4) Mengetahui contohcontoh proyek yang terkait dengan perubahan iklim yang sedang ditangani oleh ADB.

\section{STUDI LITERATUR}

\subsection{Mekanisme CDM}

Mekanisme Pembangunan Bersih (CDM) dibentuk dalam kerangka Protokol Kyoto untuk membantu negara-negara berkembang dalam memenuhi kebutuhan pembangunan yang berkelanjutan serta untuk memfasilitasi negara-negara maju (Annex I) dalam memenuhi komitmen mereka untuk menurunkan emisi. Negaranegara industri yang dikelompokan dalam annex I pada protokol Kyoto, telah berkomitmen untuk menurunkan emisi gas rumah kaca (GRK) samapai pada level tertentu hingga tahun 2012. Melalui CDM, diharapkan terjadi kelenturan dalam pemenuhan kebutuhan keberlanjutan pembangunan bagi negara berkembang melalui bantuan dari negara Annex I, sementara di sisi lain negara Annex I pun tetap dapat memenuhi komitmennya (Soemarwoto, 2004). 
Mekanisme CDM tersebut dilakukan melalui pembelian CERs yang dimiliki negara berkembang oleh negara Annex I. Namun sebelumnya, untuk mendapatkan CERs proyek CDM yang ada di negara berkembang tersebut akan diverifikasi terlebih dahulu kebenarannya oleh badan yang telah diakreditasi oleh Supervisory Executive Board. Verifikasi ini dilakukan untuk menghindari adanya penipuan. (Soemarwoto, 2004).

Menurut Niederberger (2005), proyek CDM bisa datang dari pemerintah atau sektor swasta, atau kedua-duanya. Tentu saja dengan motivasi dan pilihan-pilihan yang berbeda-beda. Dengan adanya CDM, investor asing akan berusaha masuk ke negara yang memiliki potensial CDM tinggi. Selanjutnya, Di Giuliu E (2003) mengatakan bahwa mekanisme CDM sangat sulit dilaksanakan kecuali dalam bentuk investasi asing atau foreign direct investment (FDI). Untuk lebih jelasnya, mekanisme kerja CDM dapat dilihat melalui Gambar 3.1.

\section{Gambar 3.1.}

\section{Diagram Mekanisme Kerja CDM}

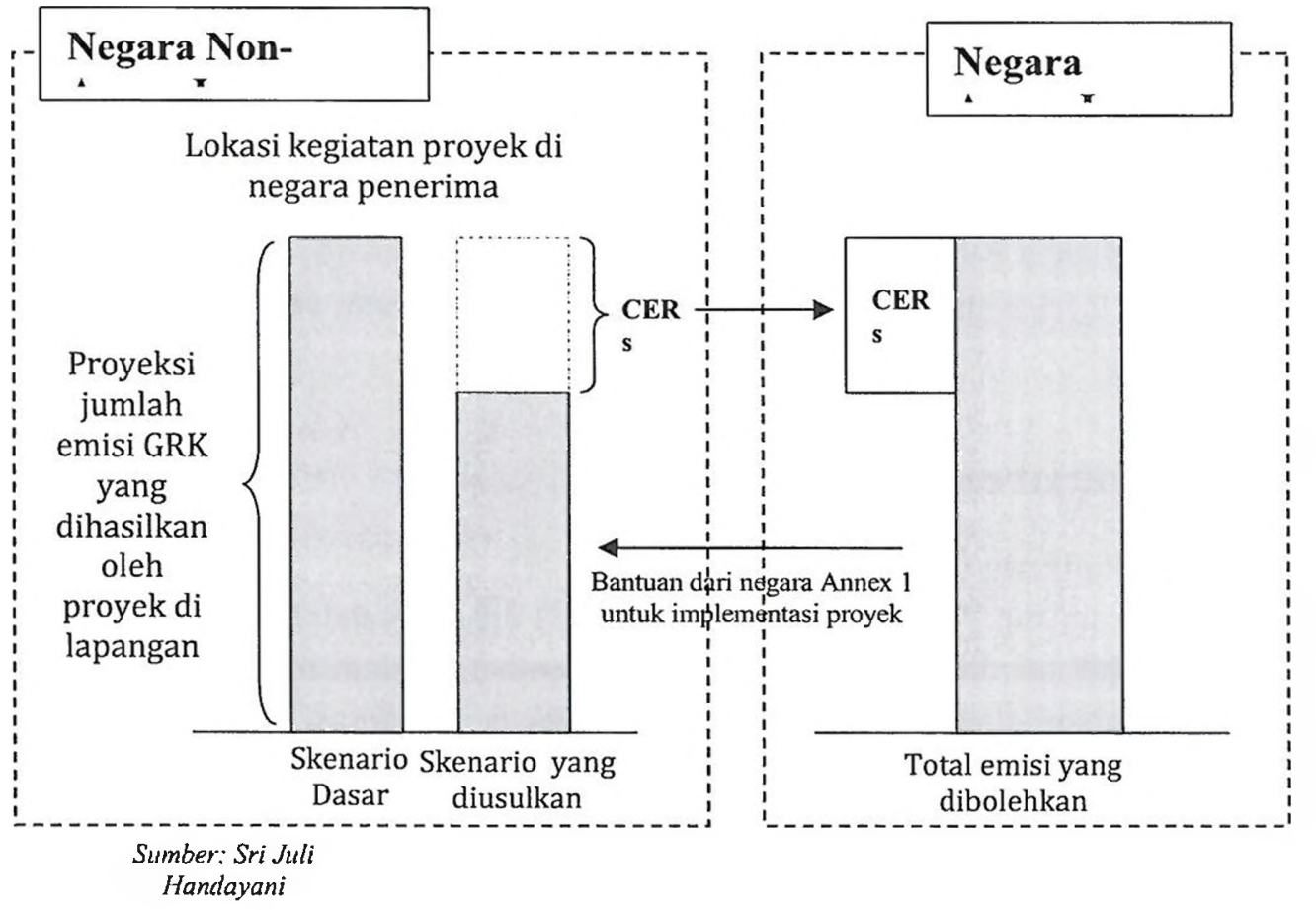




\subsection{Mekanisme REDD}

REDD merupakan kegiatan mitigasi perubahan iklim disektor kehutanan yang bersifat sukarela dan menghormati kedaulatan negara. Pada saat sidang pertemuan UNFCCC di Montreal tahun 2005, COP-11, negara-negara yang tergabung dalam koalisi pemilik hutan tropis (CfRN) mengajukan usulan akan adanya insentif atas upaya pencegahan deforestration. Kemudian pada COP-13 di Bali tahun 2007, telah disepakati hal-hal penting terkait aspek ilmiah, teknis, metodologi serta pertukaran informasi. (Nur Masripatin, 2008) 10,5

\section{METODE PENELITIAN}

Penelitian ini menggunakan metode deskriptif dengan cara observasi lapangan dan wawancara. Metode deskriptif merupakan metode untuk menggambarkan atau menganalisa suatu hasil penelitian dan tidak digunakan untuk menarik suatu kesimpulan yang lebih luas (Sugiyono (2005:21)). Studi kasus adalah salah satu jenis penelitian deskriptif yang menyelidiki suatu individu atau unit sosial yang dilakukan dengan mendalam dengan menemukan variabel yang penting pada perkembangan individu atau unit sosial yang diteliti tersebut (Furchan, 2004). Dengan metode deskriptif ini diharapkan akan tergambar mekanisme pembiayaan yang dimiliki oleh $\mathrm{ADB}$, jenis dana dan besaran pagu yang tersedia, dan persyaratannya serta best practice projects yang terkait dengan climate change yang dimiliki ADB.

Pengumpulan data dilakukan melalui studi literatur serta proses diskusi dan wawancara. Melalui interview secara mendalam ini, diharapkan dapat diketahui bagaimana gambaran program pembiayaan yang disediakan oleh ADB. Disamping itu, untuk keperluan validasi atas data yang diperoleh, maka dilakukan konfirmasi terhadap pihak-pihak yang terkait. Dengan proses pengumpulan data tersebut, diharapkan akan diperoleh gambaran penelitian yang tidak bias.

\section{GAMBARAN UMUM}

Pada tahun 2007, nilai yang dihasilkan dari penjualan kredit emisi melalui mekanisme CDM mencapai US\$7.4 milyar, atau tiga kali nilai yang dicapai pada tahun 2005. (Africa Partnership Forum, 2009). Mekanisme CDM telah membantu negara berkembang dalam memperoleh sumber pembiayaan yang signifikan yang berbasis perdagangan karbon. Akan tetapi, meskipun CDM telah sukses dalam menghasilkan proyek-proyek pengurangan karbon di banyak negara berkembang, ternyata dari total jumlah proyek CDM yang ada di dunia sampai dengan November 2009, negara-negara ASEAN hanya memberi kontribusi $12 \%$ saja. Dari 
keseluruhan kontribusi kawasan ASEAN tersebut, Indonesia hanya menyumbang usulan proyek CDM sebesar 19,5\%, atau 2,3\% dalam konteks ASEAN.

Indonesia termasuk 3 negara teraktif di kawasan Asia Tenggara yang mengajukan proposal proyek CDM - Tabel 5.1. Malaysia merupakan negara yang terbanyak, disusul kemudian oleh Thailand, Indonesia, Vietnam, baru kemudian Philippines. Dalam kasus Indonesia, dari 117 proyek CDM yang diajukan, sebanyak 22 proyek telah ditolak dan sisanya sebanyak 95 proyek dalam posisi yang beragam, ada yang diminta untuk ditinjau ulang dan ada yang masih divalidasi.

Tabel 5.1

Distribusi Proyek CDM di Asia Tenggara

\begin{tabular}{|c|c|c|c|}
\hline Negara & Total & Aktif & Ditolak \\
\hline Cambodia & 5 & 5 & 0 \\
\hline Indonesia & 117 & 95 & 22 \\
\hline Lao PDR & 2 & 2 & 0 \\
\hline Malaysia & 167 & 126 & 41 \\
\hline Philippine & 89 & 73 & 16 \\
\hline Singapura & 8 & 8 & 0 \\
\hline Thailand & 119 & 112 & 7 \\
\hline Vietnam & 93 & 85 & 8 \\
\hline
\end{tabular}

Sumber: UNEP, 2009

Dari 95 proyek CDM yang masih aktif, sebagian besar merupakan proyek dengan kategori methane avoidance sebesar 36 proyek. Kemudian disusul dengan proyek kategori biomass energy 18 proyek, landfill gas 8 proyek, dan hydro 7 proyek. Sisanya masuk dalam kategori lain yang jumlahnya kurang dari 5 proyek. Begitu pula dengan 22 proyek CDM yang ditolak. Sebagian besar proyek yang ditolak adalah proyek yang terkait dengan methane avoidance dan biomass energy.

Berdasarkan laporan Bank Dunia, 85\% kontribusi emisi terbesar bersumber dari penebangan hutan dengan menggunakan metode tebang dan bakar. Indonesia juga dinilai termasuk negara yang sangat peka dalam mengurangi pasokan bahan bakar minyak sebagai pasokan utama energi. Saat ini Indonesia memiliki potensi pengurangan emisi skala besar pada sektor energi. Potensi proyek CDM Indonesia pada sektor energi tersebut antara lain pada energi panas bumi, biomass dan hydropower. (UNEP, 2009). 
Berkaitan dengan implementasi REDD, laporan ADB telah memaparkan salah satu contoh proyek yang terkait dengan aforestration di Asia Tenggara, The RUPES Kalahan (sebuah program pengentasan kemiskinan melalui konservasi lingkungan) yang ada di Philippines. Pendukung utama program RUPES ini adalah Kalahan Educational Foundation Inc (KEF) - sebuah lembaga kemasyarakatan yang telah sukses mengorganisasi masyarakat dalam menjaga kelestarian lingkungan dan sedang berupaya untuk memperoleh kompensasi finansial atas upaya yang telah meraka lakukan. Wilayah pengelolaan hutan pada proyek ini mencapai 48.000 ha. Dengan wilayah seluas tersebut, pada tahun 2002, KEF memperkirakan sekitar 38.383 ton karbondioksida telah berhasil didaur ulang oleh hutan Kalahan (ADB, 2009).

Mereka juga telah bekerja keras dalam upaya memperoleh imbalan dari apa yang telah mereka kerjakan untuk penyerapan karbon. Mereka telah melalui suatu tahap untuk meyakinkan pihak-pihak yang mendapat manfaat dari aforestration ini untuk membiayai atau membayar atas upaya yang telah mereka lakukan. Namun demikian sampai dengan laporan ADB tersebut diturunkan, pembayaran yang sedang mereka upayakan tersebut masih belum terealisasi.

\section{ANALISIS DAN PEMBAHASAN}

Indonesia sebagai negara yang memiliki potensi hutan dan energi yang besar, semestinya juga memiliki proyek CDM yang besar di sektor tersebut. tetapi sebagaimana data UNEP tahun 2009, proyek CDM yang diajukan oleh Indonesia lebih ke kategori methane avoidance dan biomass energy. Di bidang energi, Indonesia hanya mengajukan proposal proyek untuk geothermal 5 proyek dan tidak ada proyek CDM yang diajukan yang berkaitan dengan reforestration atau aforestration.

Menurut UNEP (2009), salah satu kendala yang dihadapi dalam pembuatan proyek CDM yang berbasis pada potensi yang besar yang dimiliki oleh negara di ASEAN dalam hal ini termasuk Indonesia adalah masalah kesenjangan kesadaran akan potensi proyek CDM antar berbagai pemangku kepentingan. Berdasarkan mekanisme kerja CDM, gambar 3.1, bantuan dari negaraAannex I baru akan dilakukan jika proyek tersebut telah mendapatkan pengakuan dalam bentuk kredit CERs. Tanpa CERs, tidak akan ada aliran dana dari negara Annex I ke proyek tersebut. Padahal untuk memulai atau menginisiasi sebuah proyek CDM diperlukan investasi awal. Bagi proyek yang berbasis foreign direct investment (FDI), hal ini mungkin tidak akan menjadi kendala. Akan tetapi jika proyek ini diinisiasi oleh nonFDI, utamanya oleh pihak swasta nasional, maka hal ini akan menjadi kendala tersendiri. 
Kendala lain yang dihadapi Indonesia sebagai bagian dari negara di kawasan Asia Tenggara adalah adanya kesenjangan penguasaan teknologi, ketidaksesuaian teknologi dengan kondisi di lapangan, dan kesenjangan tenaga kerja yang mampu menganalisis dan menyiapkan proposal proyek CDM dengan baik serta adanya sumber pembiayaan untuk inisiasi proyek. Kurangnya penguasaan teknologi mengakibatkan potensi proyek CDM di suatu sektor tidak terkelola dengan optimal. Tetapi adakalanya teknologi yang telah dikuasai ternyata tidak sesuai dengan kondisi lingkungan setempat. Jika penguasaan teknologi sudah dimiliki, dan teknologi tersebut telah disesuaikan dengan kondisi di lapangan, maka yang terpenting lainnya adalah penguasaan akan analisa serta penyiapan proposal proyek tersebut. Setelah kendala-kendala tersebut di atas telah dilalui, tahap selanjutnya adalah menemukan sumber pembiayaan awal untuk menginisiasi proyek tersebut. Kendala -yang dialami negara-negara di kawasan Asia Tenggara tersebut di atas tercermin dari rendahnya proposal proyek CDM dari Asia Tenggara dan Indonesia pada khususnya dibanding total proposal proyek CDM yang ada di dunia yang hanya $12 \%$. Di samping itu, dari sisi ditribusi proyek CDM yang diajukan sebagian besar tidak mengarah pada bidang atau sektor yang potensial yang dimiliki oleh masing-masing negara Asia Tenggara tersebut.

ADB sebagai lembaga donor multilateral, saat ini sangat peduli dengan isu perubahan iklim. Hal tersebut tertuang dalam kerangka kerja strategik jangka panjangnya, Strategy 2020. Terdapat lima prioritas program yang terkait dengan perubahan iklim yang dimiliki $\mathrm{ADB}$, yaitu proyek pembangunan yang terkait dengan 1) Peningkatan energi yang lebih ramah lingkungan; 2) Pembangunan perkotaan pada transportasi yang lebih berkelanjutan; 3) Penataan tanah dan hutan untuk keperluan pengurangan emisi karbon; 4) Pengenalan pembangunan ketahanan atas perubahan iklim; 5) Penguatan kebijakan, tata kelola dan kapasitas. Kelima program tersebut, dilaksanakan oleh ADB melalui 3 modalitas, yaitu: pembiayaan, berbagi pengetahuan, dan pola kemitraan.

Dari berbagai jenis pola pembiayaan yang ada, modalitas pembiayaan yang dimiliki oleh ADB memiliki keunggulan khusus. (lihat Gambar 6.1) 


\section{Gambar 6.1.}

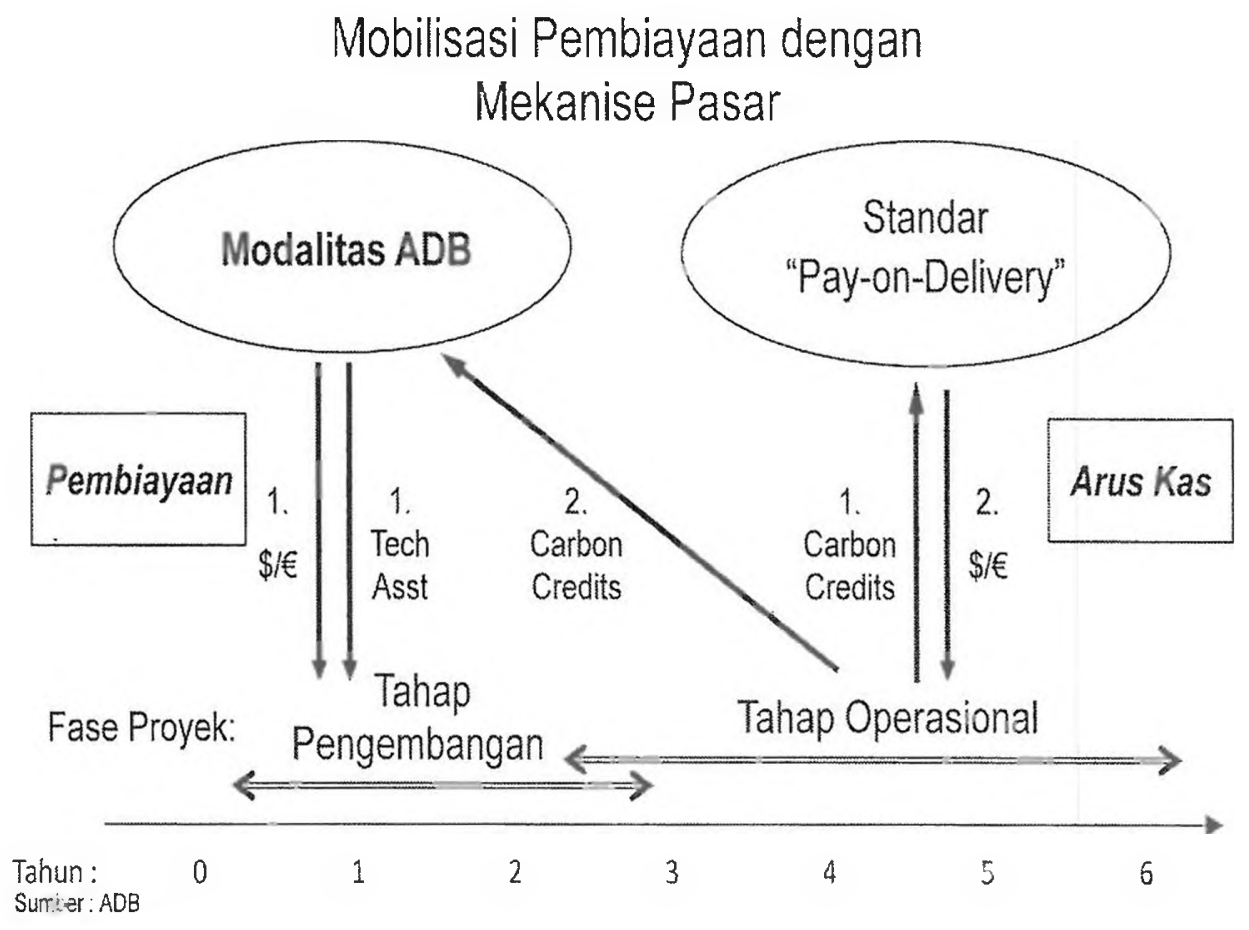

Sumber : Gil Hong Kim, ADB, 2010

Dengan skema ini, kelemahan yang ada pada mekanisme CDM yang ada pada gambar 3.1 dapat diatasi. Dalam skema yang dimilki ADB tersebut, memungkinkan sebuah proyek yang ada kaitannya dengan climate change dapat memperoleh pembiayaan pendahuluan serta technical assistant dari ADB hingga proyek tersebut memasuki masa operasional. Setelah proyek dapat beroperasi dan memperoleh kompensasi finansial dari mekanisme CDM, barulah proyek tersebut mengembalikan hutang/pembiayaan pendahuluan tersebut kepada ADB.

Di samping memiliki skema pembiayaan yang khusus, dalam kaitannya dengan climate change, ADB juga menyediakan fasilitas pendanaan mitigasi dan adaptasi climate change, baik secara individual maupun kolektif dengan bekerjasama dengan $\mathrm{ADB}$. Beberapa skema yang dapat dimanfaatkan Indonesia melalui ADB sebagai berikut :

(i) Public Financing, yang tergolong dalam dana konsesi

Pendanaan ini berasal dari sumber internal maupun eksternal ADB. Sumber dana internal ADB mencakup 
- Ordinary Capital Resources (OCR) and Asian Development Fund (ADF)

Dana OCR berasal dari paid-in capital, retained earnings (reserves), dan laba pinjaman ADB kepada negara anggotanya. Sedangkan ADF merupakan sumber dana khusus pertama $\mathrm{ADB}$ dan terbesar yang berasal dari sumber dana konsesi multilateral yang diperuntukkan khusus bagi Asia.

- ADB's Clean Energy Financing Partnership Facility (CEFPF)

Dana yang telah terkumpul sebesar US\$90 juta, dan ditargetkan dapat ditingkatkan hingga US\$250 juta.

- ADB's Climate Change Fund

Dana ini telah terisi kembali sebesar US $\$ 40$ juta yang dapat digunakan baik untuk program mitigasi maupun adaptasi Climate Change

Di samping itu terdapat pula sumber dana eksternal yang pemanfaatannya dikelola oleh ADB yaitu :

- MDBs' Climate Investment Funds

Dana sebesar US $\$ 6,3$ miliar ini bersumber dari berbagai bank pembangunan multilateral dan dikelola $\mathrm{ADB}$

- Global Environment Facility (GEF)

Trust fund sebesar US\$ 9,2 miliar yang didukung oleh dana co-financing sebesar lebih dari US $\$ 40$ miliar tersebut dikelola secara administratif oleh Bank Dunia selaku trustee. Mitra-mitra lain seperti United Nations Development Programme (UNDP), United Nations Environment Program, dan juga ADB memiliki akses langsung terhadap pendanaan ini.

- Water Financing Partnership Facility (WFPF)

Alokasi dana dari mitra pembangunan ADB sebesar US\$ 65 juta ini diperuntukkan untuk investasi, reformasi, dan pengembangan kapasitas di sektor air, termasuk proyek yang terkait Climate Change seperti pengendalian banjir.

- Poverty and Environment Fund (PEF)

Trust fund dari mitra pembangunan ADB sebesar US\$ 3,6 juta tersebut dimanfaatkan untuk proyek yang memiliki keterkaitan antara kemiskinan dan lingkungan hidup, termasuk pengurangan tingkat kerentanan terhadap bencana alam dan pencegahan bencana.

- Climate Investment Funds (CIF)

Kelompok dana yang dikelola bersama oleh ADB, Bank Dunia, dan MDBs lain tersebut terdiri dari Clean Technology Fund (CTF) dan Strategic Climate Fund (SCF). CTF dialokasikan untuk proyek-proyek yang mendukung teknologi rendah karbon, sedangkan SCF diperuntukkan untuk programprogram Climate Change yang inovatif. 
- Alokasi hibah sebesar US\$1,2 juta untuk program adaptasi Climate Change di negara-negara berkembang Asia Pasifik, yang terbuka bagi lembaga pemerintah, swasta, LSM, dan lembaga akademik. Namun dana ini telah habis digunakan.

(ii) Dana penunjang Carbon Market Initiative (CMI)

Dana penunjang pertama yaitu Asia-Pacific Carbon Fund (APCF) yang dialokasikan untuk program CMI. Dana sebesar US $\$ 151,8$ juta ini dibentuk dan dikelola oleh ADB, dan berlaku efektif sejak tanggal 1 Mei 2007. Kontributor dana adalah negara-negara Eropa yaitu Belgia, Finlandia, Luxemburg, Portugal, Spanyol, Swedia dan Swiss. Dana lain yang dapat digunakan untuk tujuan serupa adalah Future Carbon Fund (FCF).

Baik APCF maupun FCF digunakan untuk membantu mengamankan proyekproyek Clean Development Mechanism (CDM) negara-negara anggota ADB dengan cara membeli terlebih dahulu ekspektasi hasil Certified Emission Reductions (CERs) sebelum CERs siap dijual di Carbon Market. Langkah ini amat bermanfaat bagi negara berkembang yang pada umumnya terkendala dana dalam mengembangkan proyek CDM. Bila dana APCF dialokasikan untuk pembelian CERs hingga 2012, dana FCF akan dialokasikan untuk pembelian CERs setelah 2012.

(iii) Private Financing

- Direct Financing

ADB mengalokasikan pendanaan langsung ke negara-negara anggota untuk berbagai proyek terkait energi bersih dan efisiensi energi, seperti listrik tenaga angin, biomassa, matahari, dan gas alam dalam bentuk pemberian pinjaman dan penjaminan. Proyek gas alam cair Tangguh di Irian Jaya Barat dan proyek tenaga listrik hidro dan geotermal dari proyek Renewable Energy Development Project and Power Transmission Improvement merupakan contoh skema ini.

- Equity Investments

ADB berperan sebagai katalisator dalam dana ekuitas swasta (saat ini lima dana sudah dipilih $\mathrm{ADB}$ ) yang dikelola para fund manager. Dana tersebut ditanamkan dalam ekuitas perusahaan dan proyek di Asia yang berorientasi pada energi bersih, seperti energi terbarukan dan efisiensi energi

Untuk mengakses berbagai jenis pendanaan yang disediakan oleh ADB tersebut di atas, terdapat beberapa kriteria yang telah ditetapkan oleh ADB. Berdasarkan hasil wawancara dengan para narasumber $\mathrm{ADB}^{3}$, kriteria proyek

\footnotetext{
${ }^{3}$ (1) Gil Hong Kim, Director Regional and Sustainable Infrastructure Division (RSID); 2) Robert J.
}

Dobias, Senior Advisor, Climate Change Program, Regional and Sustainable Development 
Climate Change yang layak dan dapat didanai skema pendanaan ADB adalah sebagai berikut:

(i) usulan proyek memiliki dampak positif berkelanjutan bagi mitigasi dan adaptasi Climate Change serta lingkungan hidup, pro-poor, dan dapat menjadi pilot project bagi proyek lain selanjutnya

(ii) negara project proponent memiliki kapasitas memadai untuk melaksanakan proyek tersebut, dari sisi sumber daya manusia (teknis maupun administratif), infrastruktur terkait, koordinasi domestik yang baik, ketersediaan data, good governance, dan kapabilitas lembaga keuangan domestik

(iv) usulan proyek difokuskan pada sektor strategis, yaitu energi, transportasi, dan air, dan memiliki nilai ekonomis bagi negara project proponent

(iv) adanya antusiasme domestik (seperti dilakukannya konsultasi pemerintah dengan $\mathrm{ADB}$ ), dukungan kebijakan dan pendanaan dari pemerintah, dan rencana terintegrasi terkait proyek tersebut sebagaimana tercermin dalam Country Partner Strategy dan rencana pembangunan nasional.

(v) usulan proyek memiliki reduksi emisi yang dapat diverifikasi sehingga bersifat transparan dan akuntabel

Beberapa best practice projects yang telah dilaksanakan oleh ADB yang terkait dengan climate change dan menjadi pilot projects bagi proyek-proyek terkait di negara lain adalah :

1. Bangladesh: Strengthening the Resilience of the Khulna Water Sector to Climate change.

2. Pakistan: Glacial Melt and Downstream Impact on Indus-Dependent Water Resources and Energy.

3. India: National Action Plan for Climate Change: Support for the National Water Mission

4. Climate Proofing Projects Second Solomon Islands Road Improvement Project

5. Climate Proofing Projects Timor: Road Development Network Project

\section{KESIMPULAN DAN SARAN}

\subsection{Kesimpulan}

Dari hasil penelitian ini dapat ditarik beberapa kesimpulan sebagai berikut :

(1) Mekanisme pendanaan climate change yang ada (convention fund) baik melalui mekanisme CDM maupun REDD memiliki kelemahan-kelemahan. ADB menawarkan alternatif mekanisme aspek pembiayaan yang dilengkapi dengan aspek knowledge sharing dan kemitraan. Mekanisme 
yang dimiliki ADB tersebut memungkinkan sebuah proyek terkait climate change dapat memperoleh pembiayaan pendahuluan serta technical assistant dari ADB hingga proyek tersebut memasuki masa operasional. Setelah proyek mulai beroperasi dan memperoleh kompensasi finansial dari mekanisme CDM, barulah proyek tersebut berkewajiban mengembalikan hutang atau pembiayaan pendahuluan tersebut kepada ADB.

(2) Disamping skema khusus, beberapa skema yang dapat dimanfaatkan Indonesia melalui ADB adalah Public Financing (dana konsesi), dana penunjang Carbon Market Initiative (CMI), dan Private Financing.

Public financing terdiri dari Ordinary Capital Resources (OCR) and Asian Development Fund (ADF), ADB's Clean Energy Financing Partnership Facility/CEFPF (US\$ 90 juta hingga dan dapat ditingkatkan hingga US\$250 juta), ADB's Climate Change Fund (US\$ 40 juta), MDBs' Climate Investment Funds (US\$ 6,3 miliar), Global Environment Facility/GEF (US\$ 9,2 miliar, didukung oleh dana co-financing US\$ 40 miliar), Water Financing Partnership Facility/WFPF (US\$ 65 juta), Poverty and Environment Fund/PEF (US\$ 3,6 juta) Climate Investment Funds/CIF, alokasi hibah (US\$1,2 juta yang telah habis digunakan).

Dana penunjang Carbon Market Initiative/CMI terdiri dari skema AsiaPacific Carbon Fund/APCF (US\$151,8 juta) dan Future Carbon Fund/FCF. Sedangkan Private Financing terdiri dari Direct Financing dan Equity Investments

(3) Proyek Climate Change yang layak dan dapat didanai oleh ADB harus memenuhi berbagai kriteria yaitu :

(i) memiliki dampak positif berkelanjutan pro-poor, dan dapat menjadi pilot project bagi proyek lain selanjutnya

(ii) negara project proponent memiliki kapasitas memadai dalam pelaksanaaan proyek tersebut

(iii) fokus pada sektor strategis (energi, transportasi, dan air) dan memiliki nilai ekonomis

(iv) adanya antusiasme domestik dan dukungan pemerintah

(v) usulan proyek bersifat transparan dan akuntabel

(4) Beberapa jenis best practice projects pada sektor strategis terkait dengan climate change telah dilaksanakan oleh ADB di berbagai negara antara lain di Bangladesh, Pakistan, India, Solomon Islands, dan Timor. Proyekproyek tersebut dijadikan sebagai pilot projects bagi proyek-proyek serupa di negara lain. 


\subsection{Saran}

Perhatian ADB terhadap konsep pembangunan yang berwawasan lingkungan merupakan peluang sekaligus tantangan bagi negara berkembang untuk memanfaatkannya. Hutan tropis serta garis pantai yang panjang yang dimiliki Indonesia merupakan variabel perubahan iklim yang selaras dengan program climate change ADB, baik dari sisi adaptasi maupun mitigasi. Untuk itu, perlu adanya koordinasi antar instansi pemerintah dalam rangka memanfaatkan secara optimal berbagai program ADB tersebut baik dalam bentuk hibah maupun pinjaman lunak.

\section{Daftar Pustaka}

Africa Partnership Forum, 2009. Financial Resources and Investment for Climate Change. Adis Ababa

Asian Development Bank.(ADB). 2009. The Economics of Climate Change in Southeast Asia: A Regional Review.

Di Giulio,S.E., S. Migliavacca and A. Vaglio. 2003. CDM, FDI and Climate Change: Where Foreign Direct Investment Flows and Where They Should Flow, International Energy Workshop, Energy Modeling Forum (EMF). International Energy Agency (IEA) and IIASA, Austria (24-26 June)

Furchan, Arief. 2004. Pengantar Penelitian Dalam Pendidikan. Yogyakarta: Pustaka Pelajar.

Handayani, Sri Juli. 2008. Analisis Reduksi Emisi Gas Metan Melalui Proyek Mekanisme Pembangunan Bersih (CDM) pada Pabrik Kelapa Sawit Dalam Rangka Pengelolaan Lingkungan Hidup. Universitas Sumatera Utara

Kim, Gil Hong, 2010. Climate Change and Development. ADB

Masripatin, Nur.2008. Apa itu REDD ? Reducing Emissions from Deforestation and Degradation in Developing Countries. Warta Tenur Nomor 6 - September 2009.

Niederberger, A. \& Saner, R. (2005). Exploring the relationship between FDI flows and CDM potential. Transnational Corporations, 14(1), 1-40.

Soemarwoto, 0. 2004. Atur Diri Sendiri. Paradigma Baru Pengelolaan Lingkungan Hidup.Gadjah Mada University Press.

Sugiyono, 2005. Statistika Untuk Penelitian. Bandung : CV. Alfabeta.

United Nation Enviroment Programe (UNEP).2009. Status and Barriers of CDM projects in Southeast asian countries 